Available online at GSC Online Press Directory

GSC Biological and Pharmaceutical Sciences

e-ISSN: 2581-3250, CODEN (USA): GBPSC2

Journal homepage: https://www.gsconlinepress.com/journals/gscbps

(RESEARCH ARTICLE)

\title{
Studies on the public health importance of infestation of Ostracoda Vargula tsujii (Myodocopa: Cypridinidae) in some marine food fishes off Pamban, Southeast coast of India - A case study
}

\author{
S. Jayapraba * and Gopalakrishnan A. \\ Centre of Advanced Study in Marine Biology, Faculty of Marine Sciences, Parangipettai 608502, Annamalai University, \\ Tamilnadu, India.
}

Publication history: Received on 15 November 2020; revised on 23 November 2020; accepted on 25 November 2020

Article DOI: https://doi.org/10.30574/gscbps.2020.13.2.0389

\begin{abstract}
The present study was the first attempt to investigate the public health importance of infestation of Ostracoda in some marine food fishes in southeast region of Tamil Nadu India during June 2019 to May 2020 by the method of Becker's measuring utility by a single-response sequential method. Total 540 fishermen belonging to 5 villages from Ramand District were interviewed to understand the public health issues related the infestation of Ostracoda $V$. tsujii in ten major marine food fishes i.e. Parupeneus indicus, Lutjanus fulviflamma, Priacanthus hamrur (Snapper), Carangoides gymnostethus, Carangoides malabaricus, Carangoides ferdau (Carangids), Cephalopholis sonnerati, Epinephelus coioides (grouper), Lethrinus ornatus and Plectorhinchus gibbosus (sea bream). Fishermen, local whole sale buyers, small fishstall owners and fish consumers were part of respondents. It was observed that there was no difference at statistically significant level $(\mathrm{P}<0.05)$ between infested and healthy fish samples in terms of nutritional profile like protein, fat, ash, carbohydrates and mineral nutrients level. Based on the feedback and information obtained from respondents in the present study found that no incidence of health issues or risk associated with food fishes infested with Ostracoda Vargula tsujii (local name - Arattlai) or any other true parasites.
\end{abstract}

Keywords: Marine food fishes; Infestation of Ostracoda; Vargula tsujii; Pamban; Public health importance

\section{Introduction}

Food-borne parasitic infections have recently been identified as an important public health problem. Some authors have reviewed the health importance of fish parasites, their control measures and treatment [1-5]. Poor sanitation and traditional methods of food preparation have accelerated the spread of food-borne trematode infection [6]. Eating raw or improperly cooked or processed fish is the main source of these infections for humans, and this has been reported from various geographical regions [7]. The World Health Organization (WHO) has estimated that the number of people currently infected with fish-borne trematodes exceeds 18 million, and many more are at risk [8]. Freshwater and brackish water fish play a major role as the source of human infections with food-borne trematodes, and these parasites are receiving increasing attention as information on their diversity and prevalence emerges in some Asian countries [911]. Among the zoonotic nematode species that have been found, Capillaria philippinensis was first diagnosed in a Filipino patient who died of the infection some 45 years ago. Infection arises from fish that serve as intermediate hosts, thus resulting in chronic malabsorption syndrome, which has occasionally been reported to be fatal [3]. Parasitic worms are described medically as helminths, and divided into 2 broad categories: roundworms (nematodes) and tapeworms (cestodes). Fish parasites - roundworms and tapeworms - can be a health concern to humans if ingested in their live state. The parasitic helminths of concern in BC fish are anasakid roundworms found in marine-water fish (Anisakis

\footnotetext{
* Corresponding author: S. Jayapraba

Department of Coastal Aquaculture, CAS in Marine Biology, Annamalai University, Parangipettai, Tamil Nadu.

Copyright $(2020$ Author(s) retain the copyright of this article. This article is published under the terms of the Creative Commons Attribution Liscense 4.0.
} 
simplex, Pseudoterranova decipiens), and fresh-water fish tapeworms (Diphyllobothrium spp.). These worms are very common in BC fish [1].

\subsection{Trematodes/Flukes}

Among the various helminths transmitted through fish and shell fish to humans, the trematodes or flukes are responsible for causing major problem [5]. The most important parasites under the trematodes belong to the genera Clonorchis, Opisthorchis, Paragonimus, Heterophyes, Metagonimus and Nanophyetes. Trematodiasis is a serious public health problem in Asia, specifically in Southeast Asia. The liver flukes especially Clonorchis sinensis and Opisthorchis viverrini produce hepatobiliary disease. Human infection occurs after ingesting raw, undercooked. A large number of freshwater fish belonging to the family Cyprinidae (Carps) are involved in the transmission. A population of around 35 million people globally could be infected by $C$. sinensis including 15 million in China alone [12]. Another group of fish borne trematodes that transmit parasitic diseases to man is often called as "minute intestinal flukes". Globally more than 70 species of intestinal flukes are to known to infect humans mainly belonging to the family Heterophyidae and Echinostomatidae, both are well known families of fish borne parasites, many of which are distributed widely in Asia [13]. Among the Heterophyidae, noteworthy genera include Heterophyes, Haplorchis, Metagonimus [11]. Few of the heterophyids can cause significant pathology, often fatal, in the heart, brain and spinal cord of human beings [14]. It is estimated that around 18 million individuals could have been infected globally by these trematodes. Salmon poisoning in human beings is caused by another intestinal fluke-Nanophyetus salmincola which occurs in the intestine of humans and other fish eating mammals and birds. This trematode acts as a vector for a fatal rickettsial disease caused by Neorickettsia helminthoeca.

\subsection{Cestodes (Tapeworms)}

Diphyllobothriasis is an intestinal infection caused by the fish tapeworm, Diphyllobothrium latum. The infective larvae (pleurocercoid) is seen in the muscles of trout, salmon, pike and sea bass. After being ingested, the pleurocercoids attach to the mucosa of small intestine where they become adult worms of $5-10 \mathrm{~m}$ in length. Recent estimates indicate that approximately 20 million individuals could be affected by the disease [15].

\subsection{Nematodes (Roundworms)}

The most commonly encountered marine fish parasites with human infection are larval anisakid nematode that normally parasitize adult marine mammals. Although the recent popularity of raw fish preparation has resulted in an increased occurrence of human infections from this source, the total number of cases reported in America and Europe is very low but in Asia where cultural factors lead to greater risk of infection [4]. Humans could become host if they eat raw, marinated or uncooked seafood that is infected at least one L3 viable which may then cause to a severe pathology, named as 'Anisakiasis'. Anisakiasis refers to infection with larval stages of nematodes of the genera Anisakis and Pseudoterranova. Anisakis simplex is the most prevalent pathogenic species [16]. The life cycle of the anisakid nematode is complex involving small crustaceans as the first intermediate host, fishes and cephalopods as the second host and marine mammals as the final or definitive host. Humans are considered as accidental hosts of the parasite following consumption of the fish. It is a serious zoonotic disease caused by the consumption of raw or undercooked fish dishes containing the larvae of the parasite. The larvae usually penetrate the gastric wall causing acute abdominal pain, nausea, vomiting and diarrhea within few minutes to several hours resulting in gastric anisakiasis [1].

The amount of harm caused by intestinal parasitic infections to the health and welfare of individuals and communities depends on: (a) the parasite species; (b) the intensity and course of the infection; (c) the nature of the interactions between the parasite species and concurrent infections; (d) the nutritional and immunological status of the population; and (e) numerous socioeconomic factors. All the above factors may in turn be modulated by seasonal and climatic conditions. Thus, while it is generally extremely difficult to measure the suffering caused by infectious diseases, in the case of intestinal parasitic infections this is even more true because so many cases of the diseases are asymptomatic and therefore remain undetected [8]. Although the number of documented cases continues to increase, the overall risk of human infection is slight. The increasing exploitation of the marine environment by humans and the tendency to reduce cooking times when preparing seafood products both increase the chances of becoming infected with these parasites [2]. In the present study, an attempt was made to investigate the health issue if any associated with infestation of Ostracoda in some marine food fishes.

\section{Material and methods}

\subsection{Study area and Data collection}

Ten marine food fish species (Parupeneus indicus, Lutjanus fulviflamma, Priacanthus hamrur (Snapper), Carangoides gymnostethus, Carangoides malabaricus, Carangoides ferdau (Carangids), Cephalopholis sonnerati, Epinephelus coioides 
(grouper), Lethrinus ornatus and Plectorhinchus gibbosus) infested with Ostracoda Vargula tsujii were taken to study their safety and health issues if any to the fish consumers by using method of Becker's measuring utility by a singleresponse sequential method [17]. Total 540 fishermen belonging to Mandapam, Pamban, Akkal Madam, Thangachi Madam and Rameswaram were involved in this study and collected the data.

\subsection{Determination of biochemical composition}

\subsubsection{Estimation of protein}

Folin - Ciocalteau Phenol method of Lowry et al. [18] was used for the determination of the total protein in the tissue. The dried tissue sample weighing $1060.1 \mathrm{mg}$ was thoroughly homogenized with $1 \mathrm{~mL}$ of deproteinising agent (10\% TCA) by keeping the tube in ice. All samples were centrifuged for $20 \mathrm{~min}$ at $3000 \mathrm{rpm}$. The precipitate obtained was used for protein estimation. The precipitate was dissolved in $2 \mathrm{~mL} 1 \mathrm{~N} \mathrm{NaOH}$ and to $1 \mathrm{~mL}$ of this solution, freshly prepared $5 \mathrm{~mL}$ alkaline reagent was added. This was kept at room temperature for $10 \mathrm{~min}$, after which $0.5 \mathrm{~mL}$ of $1 \mathrm{~N}$ Folin - Ciocalteu reagent (Hi-media, India) was added and mixed rapidly. A standard solution was prepared by using Bovine serum albumin (Hi-media, India) crystal at a concentration of $0.2 \mathrm{mg} / \mathrm{mL}$ from the stock solution. A blank was prepared with $1 \mathrm{~mL} 1 \mathrm{~N} \mathrm{NaOH}$ and treated the same way as above. All the test tubes were kept for 30 min at room temperature in dark and the optical density (OD) of the blue colour developed was measured against the blank at 660 nm (Shimadzu UV-1800 UV spectrophotometer, Japan).

\subsubsection{Determination of total carbohydrate, lipid and ash}

Total carbohydrate was estimated by Phenol-Sulphuric acid method, described by Dubois et al. [19]. About 560.1 mg of oven-dried tissue was taken in a test tube and $1 \mathrm{~mL}$ of phenol (5\%) and $5 \mathrm{~mL}$ of concentrated sulphuric acid were added in quick succession. The tube was kept for $30 \mathrm{~min}$ at $30 \mathrm{uC}$ and the optical density of the colour developed was measured at $490 \mathrm{~nm}$ against the blank (Shimadzu UV-1800 UV spectrophotometer, Japan). Lipid content was estimated by the procedure given by Folch et al. [20]. About $50060.1 \mathrm{mg}$ of powdered oven dried tissue was mixed with $5 \mathrm{~mL}$ of chloroform: methanol (2:1) mixture tightly covered with aluminium foil and kept at room temperature for $24 \mathrm{~h}$. It was then filtered by using Whatman No. 1 filter paper $(11 \mathrm{~mm})$ and the filtered extract was taken in a pre-weighed beaker and oven dried. Beaker was weighed with lipids and the difference in weight was taken as total lipid content and percentage was calculated. Ash content was determined gravimetrically by incinerating $160.01 \mathrm{~g}$ dried sample in Muffle furnace at about $550 \mathrm{uC}$ for $6 \mathrm{~h}$ and the results are expressed in percentage $[21$.

\subsubsection{Mineral Content}

The procedure previously described by Lorenzo et al. [22] was used for mineral determination (Ca, $\mathrm{K}, \mathrm{Mg}, \mathrm{Na}, \mathrm{P}, \mathrm{Fe}, \mathrm{Mn}$, $\mathrm{Zn}$ and $\mathrm{Cu}$ ). For that purpose, a Thermo-Fisher ICAP 6000 plasma emission spectrometer (Thermo-Fisher, Cambridge, UK), equipped with a radio frequency source of $27.12 \mathrm{MHz}$, a peristaltic pump, a spraying chamber, and a concentric spray nebulizer, totally controlled with a ICP software using 99.996\% liquid argon plasma gas (Praxair, Madrid, Spain), was utilized. An external standard for setting the calibration curve was used in order to determine the mineral contents, being the results expressed as $\mathrm{mg} / 100 \mathrm{~g}$.

\subsection{Determination of microbiological parameters}

\subsubsection{Total Plate Count (TPC) test}

The working principle of TPC analysis is the calculation of the number of bacterial colonies present in the sample with dilution as needed. All work is done aseptically to prevent undesirable contamination and duplicate observation can improve accuracy. The number of bacterial colonies that can be calculated is a petri dish that has a bacterial colony between 30-300 colonies. Petri dishes, test tubes and pipettes before use are sterilized in oven at $180{ }^{\circ} \mathrm{C}$ for 2 hours. The media was sterilized in an autoclave at a temperature of $121^{\circ} \mathrm{C}$ for 15 minutes at a pressure of 1 atm. After sterilization, to keep the media from freezing the media temperature is maintained at $45-55^{\circ} \mathrm{C}$ in a water bath. The diluent solution was prepared by dissolving 8.5 grams of $\mathrm{NaCl}$ in 1 liter of water which was then sterilized in an autoclave at $121^{\circ} \mathrm{C}$ for 15 minutes. The sample of 10 grams was mashed first, then dissolved into a sterile diluent solution that has been contained with a volume reaching $100 \mathrm{ml}$ to obtain dilution $10-1$. The solution is then pelleted 1 $\mathrm{ml}$, then fed into a test tube containing $9 \mathrm{ml}$ of a sterile diluent solution to obtain 10-2 dilution. And so on until obtained dilution 10-5. From each tube the dilution reaction is taken by using a pipette of $1 \mathrm{ml}$ then put into a sterilized petri dish. Each dilution is done in duplicate. Then each cup is moved in a circle on the table so that the PCA media evenly. 
After PCA freezes, the petri dish is incubated in the incubator for 48 hours at $30^{\circ} \mathrm{C}$; the petri dish is placed upside down in the incubator [23].

Yeast and mould: Fish muscle sample was homogenized using stomacher blender and made serial dilution with distilled water, then added $1 \mathrm{ml}$ of solution into the sterile petriplate having chloramphenicol yeast agar medium. Incubated the petriplate at $25^{\circ} \mathrm{C}$ for 3 to 5 days in horizontal position, then colonies were counted using colony counter [24].

E. coli: Fish tissue sample was homogenized, taken $25 \mathrm{~g}$ of this sample into $225 \mathrm{ml}$ of buffered peptone water, then $1 \mathrm{ml}$ of this diluted solution was added into $9 \mathrm{ml}$ of $0.1 \%$ peptone water. Then added $1 \mathrm{ml}$ of diluted sample into, petriplate having EMB/MacConkey/Tergitol agar medium then incubated the petriplate at $37^{\circ} \mathrm{C}$ for 24 hours in inverted position. Then colonies formed (green metallic sheen color colonies on EMB agar medium, pink color colonies on MacConkey agar medium yellow color surrounded colonies on Tergitol agar medium) were counted with colony counter and reported [25].

Salmonella \& Shigella: Fish tissue sample was homogenized, taken $25 \mathrm{~g}$ of this sample into $225 \mathrm{ml}$ of buffered peptone water and incubated the broth at $37^{\circ} \mathrm{C}$ for 24 hours. Then $1 \mathrm{ml}$ was transferred to Rappaport Vassiliadis medium and incubated at $42^{\circ} \mathrm{C}$ for 24 hours, then streak it on xylose lysine deoxycholate agar medium and incubated at $37^{\circ} \mathrm{C}$ for 24 hours [26]. For enumeration of Shigella, fish tissue sample was Homogenized, taken $25 \mathrm{~g}$ of this sample into $225 \mathrm{ml}$ of Muller Kauffmann broth and incubated at $37^{\circ} \mathrm{C}$ for 24 hours, then streak it on Deoxycholate citrate agar medium, then petriplate was incubated at $37^{\circ} \mathrm{C}$ for 24 to 48 hours [27].

\subsection{Statistical Analysis}

A total of 540 fishermen were interviewed and collected the data on risk and health issues associated with infestation of Ostracoda in 10 marine food fishes. Statistical analyses were performed using IBM SPSS Statistics 21 software (IBM Corp., Armonk, NY, USA). Normal distribution and homogeneity of variance were previously tested (Shapiro-Wilk). Data were submitted for analysis of variance (ANOVA) and Duncan test, when ANOVA had a significant value $(p<0.05)$. The values were given in terms of mean values and standard error of the mean (SEM).

\section{Results}

Of 10 species studied, 3 fishes of snapper and carangoides each and 2 species of grouper and sea bream each. Proximate composition of muscle of 10 food fishes studied is given in the Table 1 . Total moisture content ranged between $65.07 \pm$ $6.6 \%$ to $70.24 \pm 6.0 \%$ with lowest level in C. ferdau, an ostracoda infested sample and highest in healthy L. ornatus. The lowest fat level was observed in healthy muscle of sea bream P. gibbosus $(5.04 \pm 0.30 \%)$ while highest value recorded in muscle of grouper fish $C$. sonnerati i.e. $5.81 \pm 0.80 \%$, however no variation was found between the fishes studied at statistically significant level. Protein content in the tissue of all 10 fish species studied had little bigger range i.e. 17.08 \pm 1.8 to $20.99 \pm 1.5$, lowest in L ornata. and highest in C. malabaricus, a carangoide fish. In snapper fishes it ranged between $18.83 \pm 1.5 \%$ and $20.18 \pm 17 \%$; the range was $18.85 \pm 1.3 \%$ to $20.99 \pm 1.5 \%, 17.11 \pm 1.6 \%$ to $18.51 \pm 1,9$ and $17.08 \pm 1.8 \%$ to $19.14 \pm 2.1 \%$ in carangoides, grouper and sea bream fishes respectively. The carbohydrate level in muscle of all fishes tested ranged between $3.11 \pm 0.29 \%$ and $5.81 \pm 0.30 \%$ and found not much difference between fishes tested and also difference between healthy and infested fish samples. Total plate count tested was 2500 and yeast and mould was 100, no pathogenic bacteria like Salmonella and Shigella were found any of the fish sample tested in the present study. Thus no statistically significant $(p<0.05)$ difference in the biochemical composition like carbohydrate, protein, fat, carbohydrate and ash content between infested and healthy fish samples were found and all fish samples tested were free from pathogenic microbes. Some food fishes infested with Ostracoda $V$. tsujii is shown Figure 1, and Figure 2 shows the close view of $V$. tsujii. Highest percentage of prevalence was recorded in fish $P$. inducus ranging from $6.58 \%$ to $38.36 \%$ (ave. $21.33 \%$ ) but varying with different season, it was also observed that some fishes species studied were not infested with $V$. tsujii during some seasons (Figure 3). 
Table 1 Nutritional composition and microbiological parameters of muscle of some marine food fishes infested by Ostracoda Vargula tsujii

\begin{tabular}{|c|c|c|c|c|c|c|c|c|c|}
\hline Host fishes & $\begin{array}{l}\text { Sample } \\
\text { condition }\end{array}$ & $\begin{array}{l}\text { Moisture } \\
(\%)\end{array}$ & Total fat (\%) & $\begin{array}{l}\text { Total protein } \\
(\%)\end{array}$ & Ash (\%) & $\begin{array}{l}\text { Total } \\
\text { carbohydrate }(\%)\end{array}$ & TPC & $\begin{array}{l}\text { Yeast \& } \\
\text { Mould }\end{array}$ & $\begin{array}{l}\text { Pathogenic } \\
\text { bacteria* }^{*}\end{array}$ \\
\hline \multirow[t]{2}{*}{ P. indicus } & Infested & $68.12 \pm 4.1$ & $6.61 \pm 0.30$ & $19.25 \pm 1.9$ & $1.40 \pm 0.10$ & $4.44 \pm 0.22$ & 2500 & 100 & Negative \\
\hline & Healthy & $67.34 \pm 3.8$ & $6.20 \pm 0.21$ & $20.18 \pm 17$ & $1.45 \pm 0.09$ & $4.47 \pm 0.11$ & 2500 & 100 & Negative \\
\hline \multirow[t]{2}{*}{ L. fulviflamma } & Infested & $68.23 \pm 5.0$ & $7.17 \pm 0.22$ & $19.20 \pm 2.1$ & $1.61 \pm 0.11$ & $3.37 \pm 0.20$ & 2500 & 100 & Negative \\
\hline & Healthy & $67.15 \pm 6.6$ & $7.25 \pm 0.31$ & $18.83 \pm 1.5$ & $1.39 \pm 0.12$ & $4.53 \pm 0.08$ & 2500 & 100 & Negative \\
\hline \multirow[t]{2}{*}{ P. hamrur } & Infested & $68.50 \pm 4.9$ & $5.62 \pm 0.28$ & $19.02 \pm 2.0$ & $1.80 \pm 0.11$ & $4.83 \pm 0.23$ & 2500 & 100 & Negative \\
\hline & Healthy & $67.22 \pm 3.8$ & $6.51 \pm 033$ & $18.44 \pm 1.4$ & $1.78 \pm 0.07$ & $5.16 \pm 0.41$ & 2500 & 100 & Negative \\
\hline \multirow[t]{2}{*}{ C. gymnostethus } & Infested & $67.20 \pm 6.1$ & $7.13 \pm 0.27$ & $19.16 \pm 1.7$ & $1.40 \pm 0.10$ & $4.15 \pm 0.70$ & 2500 & 100 & Negative \\
\hline & Healthy & $66.05 \pm 6.0$ & $7.17 \pm 0.29$ & $19.12 \pm 2.2$ & $1.32 \pm 0.12$ & $5.81 \pm 0.30$ & 2500 & 100 & Negative \\
\hline \multirow[t]{2}{*}{ C. malabaricus } & Infested & $67.88 \pm 5.4$ & $5.14 \pm 0.40$ & $19.51 \pm 2.0$ & $1.55 \pm 0.00$ & $3.52 \pm 0.39$ & 2500 & 100 & Negative \\
\hline & Healthy & $68.19 \pm 3.8$ & $5.81 \pm 0.26$ & $20.99 \pm 1.5$ & $1.54 \pm 0.13$ & $3.29 \pm 0.26$ & 2500 & 100 & Negative \\
\hline \multirow[t]{2}{*}{ C. ferdau } & Infested & $65.07 \pm 6.6$ & $6.60 \pm 0.26$ & $19.43 \pm 1.7$ & $1.38 \pm 0.13$ & $4.07 \pm 0.48$ & 2500 & 100 & Negative \\
\hline & Healthy & $66.29 \pm 6.3$ & $6.15 \pm 0.43$ & $18.85 \pm 1.3$ & $1.41 \pm 0.11$ & $5.63 \pm 0.35$ & 2500 & 100 & Negative \\
\hline \multirow[t]{2}{*}{ C. sonnerati } & Infested & $69.30 \pm 4.4$ & $7.18 \pm 0.41$ & $18.51 \pm 1,9$ & $1.60 \pm 0.10$ & $5.21 \pm 0.24$ & 2500 & 100 & Negative \\
\hline & Healthy & $67.80 \pm 5.2$ & $7.81 \pm 0.38$ & $18.20 \pm 2.1$ & $1.55 \pm 0.05$ & $4.49 \pm 0.16$ & 2500 & 100 & Negative \\
\hline \multirow[t]{2}{*}{ E. coioides } & Infested & $69.05 \pm 5.6$ & $7.11 \pm 0.38$ & $17.11 \pm 1.6$ & $1.45 \pm 0.07$ & $5.05 \pm 0.17$ & 2500 & 100 & Negative \\
\hline & Healthy & $68.45 \pm 6.3$ & $7.07 \pm 0.30$ & $17.97 \pm 1.6$ & $1.61 \pm 0.13$ & $4.17 \pm 0.42$ & 2500 & 100 & Negative \\
\hline \multirow[t]{2}{*}{ L. ornatus } & Infested & $69.13 \pm 7.4$ & $6.77 \pm 0.40$ & $18.15 \pm 1.8$ & $1.60 \pm 0.11$ & $3.11 \pm 0.29$ & 2500 & 100 & Negative \\
\hline & Healthy & $70.24 \pm 6.0$ & $6.82 \pm 0.41$ & $17.08 \pm 1.8$ & $1.70 \pm 0.13$ & $3.80 \pm 0.42$ & 2500 & 100 & Negative \\
\hline \multirow[t]{2}{*}{ P. gibbosus } & Infested & $67.66 \pm 6.7$ & $5.91 \pm 0.32$ & $19.14 \pm 2.1$ & $1.60 \pm 0.12$ & $4.91 \pm 0.58$ & 2500 & 100 & Negative \\
\hline & Healthy & $67.15 \pm 7.1$ & $5.04 \pm 0.30$ & $18.45 \pm 2.0$ & $1.48 \pm 0.14$ & $4.61 \pm 0.55$ & 2500 & 100 & Negative \\
\hline
\end{tabular}


Table 2 Mineral composition of muscle of some marine food fishes infested by Ostracoda Vargula tsujii (mg/100 g)

\begin{tabular}{|c|c|c|c|c|c|c|c|c|c|c|}
\hline Host fishes & $\begin{array}{l}\text { Sample } \\
\text { condition }\end{array}$ & Calcium & Magnesium & Phosphorous & Potassium & Sodium & Copper & Iron & Zinc & Manganese \\
\hline \multirow[t]{2}{*}{ P. indicus } & Infested & 29.12 & 36.33 & 265.55 & 345.22 & 110.28 & 0.27 & 1.10 & 0.61 & 21.12 \\
\hline & Healthy & 29.28 & 36.12 & 271.20 & 361.65 & 115.17 & 0.30 & 1.21 & 0.55 & 20.02 \\
\hline \multirow[t]{2}{*}{ L. fulviflamma } & Infested & 26.10 & 42.25 & 320.00 & 365.15 & 97.23 & 0.21 & 1.08 & 0.34 & 19.10 \\
\hline & Healthy & 27.05 & 43.12 & 325.27 & 377.71 & 102.40 & 0.33 & 1.25 & 0.44 & 18.50 \\
\hline \multirow[t]{2}{*}{ P. hamrur } & Infested & 29.55 & 36.22 & 254.50 & 350.16 & 123.00 & 0.41 & 0.99 & 0.71 & 21.35 \\
\hline & Healthy & 28.72 & 36.20 & 258.20 & 361.40 & 127.20 & 0.36 & 1.01 & 0.23 & 22.31 \\
\hline \multirow[t]{2}{*}{ C. gymnostethus } & Infested & 30.33 & 40.75 & 265.15 & 404.61 & 87.64 & 0.25 & 0.88 & 0.21 & 21.50 \\
\hline & Healthy & 31.29 & 41.63 & 277.23 & 411.22 & 91.43 & 0.20 & 1.51 & 0.13 & 21.29 \\
\hline \multirow[t]{2}{*}{ C. malabaricus } & Infested & 29.44 & 45.90 & 306.18 & 381.35 & 99.10 & 0.38 & 1.30 & 0.27 & 20.00 \\
\hline & Healthy & 29.96 & 44.07 & 310.36 & 377.84 & 103.20 & 0.51 & 1.75 & 0.65 & 20.71 \\
\hline \multirow[t]{2}{*}{ C. ferdau } & Infested & 31.68 & 38.46 & 344.20 & 346.29 & 102.20 & 0.37 & 1.32 & 0.60 & 19.49 \\
\hline & Healthy & 32.50 & 38.64 & 335.00 & 351.58 & 111.90 & 0.28 & 1.24 & 0.28 & 18.19 \\
\hline \multirow[t]{2}{*}{ C. sonnerati } & Infested & 30.04 & 39.30 & 248.20 & 432.50 & 121.80 & 0.33 & 1.11 & 0.48 & 17.30 \\
\hline & Healthy & 30.62 & 39.18 & 251.30 & 427.02 & 107.05 & 0.30 & 0.87 & 0.53 & 20.10 \\
\hline \multirow[t]{2}{*}{ E. coioides } & Infested & 27.28 & 38.35 & 277.20 & 418.50 & 107.50 & 0.26 & 1.42 & 0.71 & 28.21 \\
\hline & Healthy & 28.15 & 39.50 & 281.61 & 420.80 & 88.48 & 0.27 & 1.33 & 0.57 & 27.16 \\
\hline \multirow[t]{2}{*}{ L. ornatus } & Infested & 29.70 & 36.05 & 301.28 & 366.10 & 115.20 & 0.29 & 1.62 & 0.65 & 19.10 \\
\hline & Healthy & 30.41 & 37.46 & 303.98 & 360.00 & 117.20 & 0.33 & 1.45 & 0.61 & 18.77 \\
\hline \multirow[t]{2}{*}{ P.gibbosus } & Infested & 33.58 & 37.10 & 245.85 & 335.46 & 109.50 & 0.25 & 0.99 & 0.70 & 20.17 \\
\hline & Healthy & 34.17 & 37.82 & 247.12 & 341.14 & 121.00 & 0.24 & 0.91 & 0.73 & 19.18 \\
\hline
\end{tabular}


The content of minerals in the muscle of 10 food fishes studied is given in Table 2. Both macro and micro mineral nutrients healthy and infested fish samples were analyzed. Macro-minerals like potassium and phosphorous were followed by other mineral nutrients, however, not much variable in the content was found between infested and healthy fishes of all 10 species studied. The phosphorous level was found from $245.85 \mathrm{mg} \mathrm{g}^{-1}$ to $344.20 \mathrm{mg} \mathrm{g}^{-1}$ and potassium was marginally higher then phosphorous i.e. it ranged between $335.46 \mathrm{mg} \mathrm{g}^{-1}$ and $432.50 \mathrm{mg} \mathrm{g}^{-1}$, calcium (26.10 $33.58245 .85 \mathrm{mg} \mathrm{g}^{-1}$ ) and magnesium (36.12 - $45.90 \mathrm{mg} \mathrm{g}^{-1}$ ), the other two major minerals were found much less than potassium and phosphorous. Contents of micro mineral nutrients like sodium, manganese, $\mathrm{z}$ iron, zinc and copper are found in decreasing order, but none of found at statistically significant level $(p<0.05)$. A similar phenomenon occurred.

Table 3 shows the demographics respondents in the present study. Total 540 people were interviewed to understand the public health issue related to the consumption of marine food fishes infested with Ostracoda $V$. tsujii. Of 540 respondents, 60 were from below 20 years of age group, 165, 90, 75 and 60 were from 21-30, 31-40, 41-50 and 50-51 years of age group respectively and 90 people were from above 60 years of age group. Out of 540 people interviewed, no single respondent had reported that they faced any health issues due to consumption of fishes infested with Arattalai (Ostracoda, V. tsujii). However, 1.48\% of respondents belonging to 31-40 years of age group, 0.93\% of age group 41-50 and 51-50 each recorded that they had suffered from mild stomach pain and nausea due to intake of fish with other disease. Similarly $2.22 \%$ of people more than 60 years of age had faced some healthy issue occasionally by consumption of disease affected fish but not due to consumption of fish infested with Arattalai (Ostracoda V. tsujii.

Table 3 Demographics of the respondents $(n=540)$

\begin{tabular}{|l|l|l|l|l|l|l|l|l|}
\hline $\begin{array}{l}\text { Age } \\
\text { group } \\
\text { (years) }\end{array}$ & $\begin{array}{l}\text { Total } \\
\text { interviewed } \\
\text { (No.) }\end{array}$ & Frequency & $\begin{array}{l}\text { Percent } \\
\text { (\%) }\end{array}$ & $\begin{array}{l}\text { Involved in } \\
\text { fishing } \\
\text { activity (no.) }\end{array}$ & $\begin{array}{l}\text { Percent } \\
\text { (\%) }\end{array}$ & $\begin{array}{l}\text { Average } \\
\text { monthly } \\
\text { income (INR) }\end{array}$ & $\begin{array}{l}\text { Education } \\
\text { (Literate } \\
\text { not } \\
\text { graduated) }\end{array}$ & $\begin{array}{l}\text { Percent } \\
\text { but }\end{array}$ \\
\hline$\leq 20$ & 60 & 12 & 2.22 & 35 & 58.33 & 8500 & 58 & 96.67 \\
\hline $21-30$ & 165 & 9 & 1.67 & 135 & 81.82 & 15500 & 160 & 96.97 \\
\hline $31-40$ & 90 & 15 & 2.78 & 65 & 72.22 & 15000 & 82 & 91.11 \\
\hline $41-50$ & 75 & 15 & 2.78 & 55 & 73.33 & 12500 & 70 & 93.33 \\
\hline $51-60$ & 60 & 10 & 1.85 & 40 & 66.67 & 10500 & 55 & 91.67 \\
\hline$\geq 60$ & 90 & 5 & 0.93 & 45 & 50.00 & 7500 & 65 & 72.22 \\
\hline
\end{tabular}
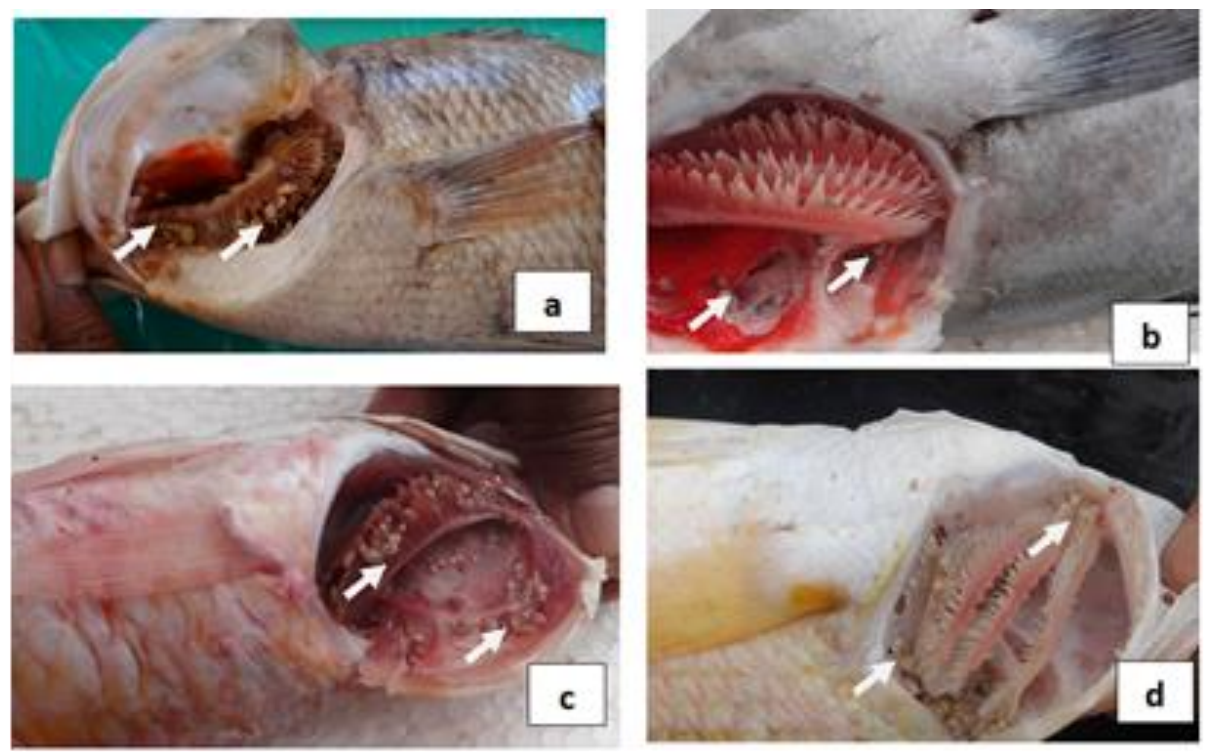

Figure 1 Infestation of Ostracoda Vargula tsujii in common marine food fishes; a. Lethrinus ornata, b. Plectorhinchus gibbosus, c. Parupeneus indicus d. Lutjanus fulviflamma 


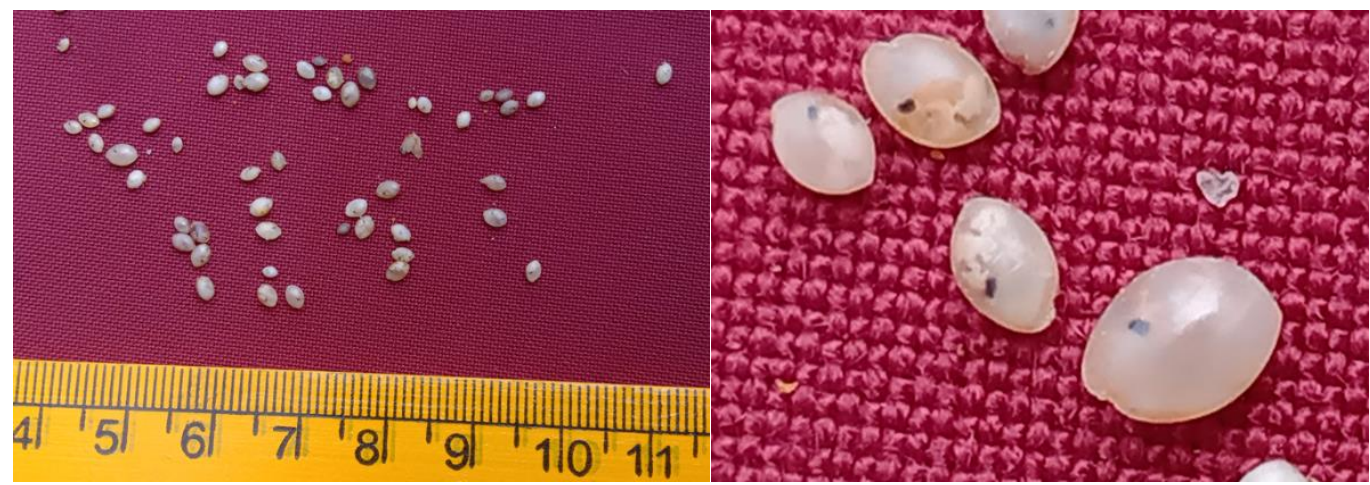

Figure 2 Ostracoda Vargula tsujii collected from gills of Lethrinus ornata, a. Total collection, b. Closer view (size ranges from $1.5 \mathrm{~mm}$ to $3.0 \mathrm{~mm}$ )

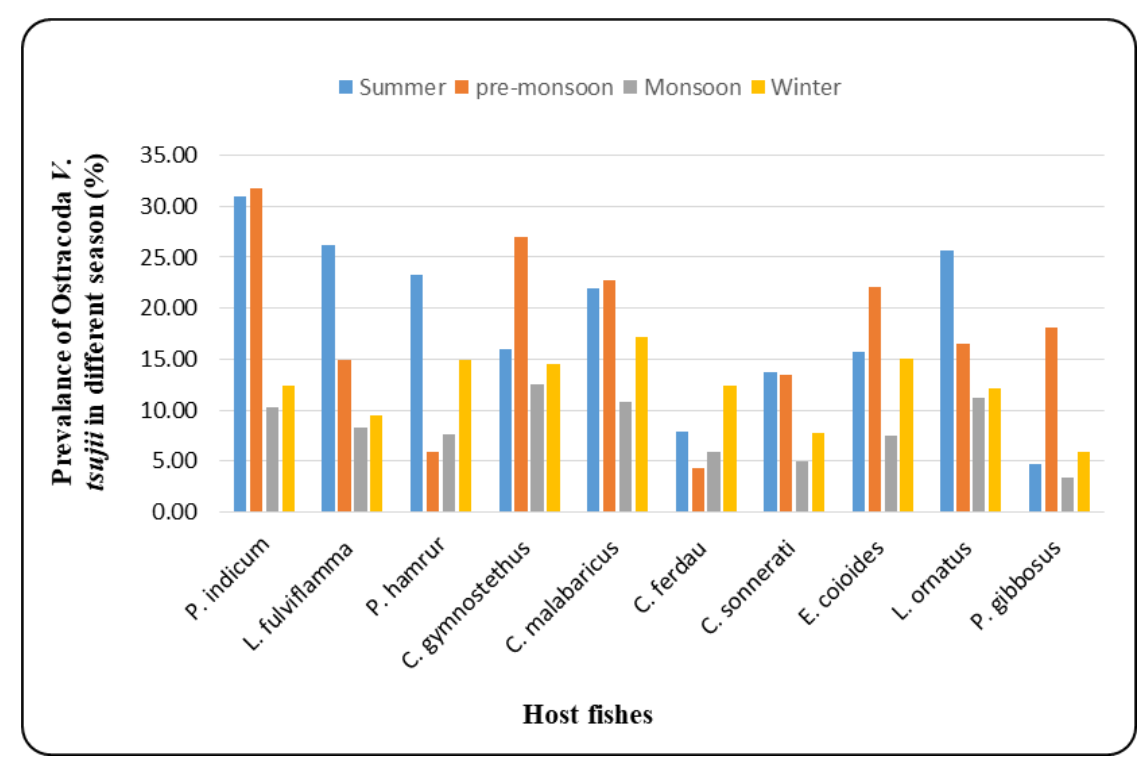

Figure 3 Prevalence of infestation of Ostracoda $V$. tsujii in some marine food fishes.

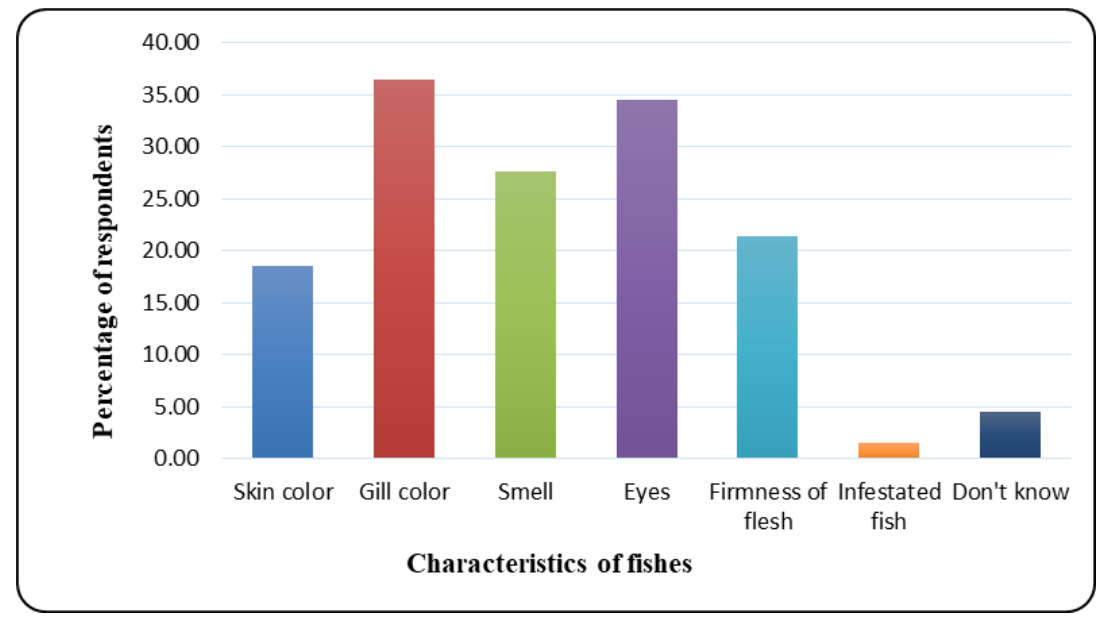

Figure 4 Consumer perception with regards to quality of fishes $(n=540)$ 


\section{Discussion}

All living organisms, including fish, can have parasites. Parasites are a natural occurrence, not contamination. They are as common in fish as insects are in fruits and vegetables. Parasites do not present a health concern in thoroughly cooked fish. Parasites become a concern when consumers eat raw or lightly preserved fish such as sashimi, sushi, ceviche, and gravlax. When preparing these products, use commercially frozen fish. Alternatively, freeze the fish to an internal temperature of $-4^{\circ} \mathrm{F}$ for at least 7 days to kill any parasites that may be present [2]. Roundworms called nematodes are the most common parasite found in marine fishes. Some people call these nematodes herring worms or cod worms. All are in the family Anisakidae and are anisakid nematodes. Freshwater fish like trout and fish that spend part of their life in freshwater such as salmon may carry Diphyllobothrium tapeworm larvae. These small, whitish, and somewhat flabby worms are common in salmon from some areas of Alaska. The life cycle of an anisakid nematode begins when seals or sea lions eat infected fish. The larval nematodes grow to maturity, and the marine mammal excretes the nematode eggs into the sea where they hatch. The larvae then develop into the form we see in fish.

Nematodes rarely cause health problems because they are uncommon in fish fillets and normal cooking easily destroys them. In most cases, swallowing a live nematode is harmless. The nematode passes through the intestine without causing problems. In rare cases, swallowing a live nematode larva can cause severe gastric upset called anisakiasis. This happens when the nematode attaches to or penetrates the intestinal lining. Swallowing live tapeworm larvae can cause a tapeworm infestation. The tapeworms may live in the human intestinal tract for several years. Symptoms can include abdominal pain, weakness, weight loss and anemia [2]. Cooking fish to an internal temperature of $140^{\circ} \mathrm{F}$ will kill all fish nematodes and tapeworms. Normal cooking procedures generally exceed this temperature. Heating hot-smoked fish to an internal temperature of at least $140^{\circ} \mathrm{F}$ will kill all fish nematodes and tapeworms. Normal hot-smoking procedures generally exceed this temperature. Dry-salting fish, or curing them in a saturated salt brine, for 5-7 days before pickling will kill nematodes and tapeworms. Pickling without salt curing may not destroy some nematodes. Eating raw fish, just like eating raw meat or poultry, is riskier than eating cooked products. To minimize the risk, avoid eating raw or lightly marinated seafood unless the fish is free of parasites, or has been properly frozen. It is a common practice to use frozen fish in countries where raw fish dishes are traditional. Japan's National Health Institute recommends freezing fish to $4^{\circ} \mathrm{F}$ for several hours when preparing raw fish, or avoiding fish that are susceptible to parasites [2].

In the present investigation, no significant variation was observed in the nutritional composition of all 10 food species studied and none of the fish samples tested was found to have contamination of pathogenic bacteria. Total plate count and yeast and mould were within permissible level. Regarding macro-micro mineral nutritional, Phosphorous and potassium were the minerals that showed the higher contents, with values that exceeded in all cases $300 \mathrm{mg} / 100 \mathrm{~g}$. regardless of healthy and infested fish sample with infestation of Arattalai ( $V$. tsujii) In contrast, the contents of copper and zinc found in all the samples tested were very low (less than $1 \mathrm{mg} \mathrm{g}^{-1}$ ).

A small percentage of respondents aged more than 60 years $(2.22 \%)$ recorded that they faced minor health issue due to consumption of spoilt fish but no respondent recorded any health issue faced so far by consumption of fish infested with Arattalai (Ostracoda Vargula tsujii). The majority of respondents opined that quality of fish is generally judged by close observation of the eyes, gill colour and the smell of the fish and infestation is not generally considered as one of the quality parameters and only less than 1\% respondents said they check the infestation of parasites in fishes (Figure 4). With regard to knowledge about the Arattali infestation fishes, only some $70 \%$ people with age group less than 20 years age are not much aware of infestation otherwise majority of the respondents were aware of infestation of Arattali in food fishes.

\section{Conclusion}

Based on the results obtained in the present study and fee-back obtained from 540 volunteers, it can be concluded that infestation of Ostracoda $V$. tsujii in the marine food fishes had not caused any public health issue and fishes with such kind of infestation is safe to consume. 


\section{Compliance with ethical standards}

\section{Acknowledgments}

The authors are very grateful to the Prof. M. Srinivasan, Dean, CAS in Marine Biology, Annamalai University for his constant encouragement and support for the present investigation. Respondents participated in the study are gratefully acknowledged. Thanks are due to Mrs. Malar and Mr. Senthil who helped the authors in carrying out the interview with respondents successfully. K. Karthikeyan is gratefully acknowledged for analysing the data statistically and given readings and observations. The authors are also thankful to Ministry of Environment, Forest \& Climate Change (MoEF\&CC), Project No. 22018-05/2019-CS (Tax) for supporting in carrying out the work. The authors are also thankful to Fishermen and women of Gulf of Mannar, Tamilnadu.

\section{Statement of informed consent}

Informed consent was obtained from all individual participants included in the study.

\section{References}

[1] Carlos AM. Lima dos Santos and Peter Howgate. Fishborne zoonotic parasites and aquaculture: A review Aquaculture. 2013; 318: 253-261.

[2] Hilderbrand KS, Price RJ, Olson RE. Parasites in marine fishes, questions and answers for seafood retailers," Publication SG 79/Reprinted Oregon State University Extension Service, Oregon State University, Corvallis, Oregon. October 1985.

[3] Khalil MI, El-Shahawy IS, Abdelkader HS. Studies on some fish parasites of public health importance in the southern area of Saudi Arabia. Braz J Vet Parasitol. Jaboticabal. 2014; 23(4): 435-442.

[4] Olson RE. Marine fish parasites of public importance In: DF Kramer and J Liston (Eds) Seafood quality determination, Proceeding of an international Symposium Coordinated by the University of Alaska, Sea grant college program, Ancorage Alaska USA, 10-14 November 1986.

[5] Sangaran A, Bino Sundar ST. Fish and shell fish borne parasitic infection - A review Intl. J Sci Env \& Tech. 2016; 5(5): 2954-2958

[6] Phan VT, Ersboll AK, Nguyen KV, Madsen H, Dalsgaard A. Farm-level risk factors for fish-borne zoonotic trematode infection in integrated small-scale fish farms in northern Vietnam. 2010; PLOS Negl Trop Dis 4(7): e472; doi.org/10.1371/journal.pntd.0000742

[7] Park CW, Kim JS, Joo HS, Kim J. A human case of Clinostomum complanatum infection in Korea. Korean J Parasitol. 2009; 47(4): 401-404.

[8] WHO. Bulletin of the World Health Organization. 1987; 65(5): 575-588.

[9] Jithendran KP (2018), MEPDA, India News Letter, 2008-October, 31-35.

[10] Chai JY. Intestinal trematode infections in Korea. In: Arizono N, Chai JY, Nawa Y, Takahashi Y, editors. Asian parasitology. Chiba: Federation of Asian Parasitologists, Foodborne helminthiasis. 2005; 1: 79-102.

[11] Chai JY, Shin EH, Lee SH, Rim HJ.Foodborne intestinal flukes in Southeast Asia. Korean J Parasitol. 2009; 47:69102.

[12] Tang Ze-Li, Huang Y, Yu Xin-Bing. Current status and perspectives of Clonorchis sinensis and clonorchiasis: epidemiology, pathogenesis, omics, prevention and control. Infectious Diseases of Poverty. 2016; 5: 71.

[13] Yu SH, Mott KE. Epidemiology and morbidity of food borne intestinal trematode infections. Trop Dis Bull. 1994; 91: 125-152.

[14] Toledo R, Esteban JG, Fried B. Immunology and pathology of intestinal trematodes in their definitive hosts. Adv Parasitol. 2006; 63: 286-365.

[15] Scholtz T, Garcia HH, Kuchta R, Wicht B. Update on the human broad tapeworm (Genus Diphyllobothrium), including clinical relevance. Clin Microbiol Rev. 2009; 22: 146-160.

[16] Torres P, Jercic MI, Weitz JC, Dobrew EK, Mercado RA. Human pseudoterranovosis, an emerging infection in Chile. J Parasitol. 2007; 93: 440-443.

[17] Becker G, DeGroot M, Marschak J. Measuring utility by a single-response sequential Method. Behav Sci. 1964; 9 : 226-236. 
[18] Lowry OH, Rosebrough NJ, Farr AL, Randall RJ. Protein measurement with the folin-phenol reagents. J Biol Chem. 1951; 193: 265-273.

[19] Dubois M, Giles KA, Hamilton JK, Rebors PA, Smith F. Calorimetric method for determination of sugars and related substances. Analyt Chem. 1956; 28: 350-356.

[20] Folch J, Lees M, Stanley GHS. A simple method for the isolation and purification of total lipids from animal tissues. J Biol Chem. 1957; 226: 497-509.

[21] AOAC.Official methods of analyses of association of analytical chemist (15th ed.).Washington DC. 1990.

[22] Lorenzo JM, Bermudez R, Domínguez R, Guiotto, A. Franco D, Purrinos L. Physicochemical and microbial changes during the manufacturing process of dry-cured lacon salted with potassium, calcium and magnesium chloride as a partial replacement for sodium chloride. Food Control. 2015; 50: 763-769.

[23] Mailoa MN, Tapotubun AM, Matrutty TEAA. Analysis Total Plate Count (TPC) On Fresh Steak Tuna Applications Edible Coating Caulerpa sp During Stored at Chilling Temperature. IOP Conf. Series: Earth and Environmental Science. 2017; 89: 12014

[24] IS 5403 (1999): Method for Yeast and Mould Count of Foodstuffs and annimal feeds [FAD 15: Food Hygiene, Safety Management and Other Systems]

[25] IS 5887 (Part 1: 1976 and Reaffirmed in 2013): Methods of bacteria response for food poisoning part I-isolation, identification and enumeration of Escherichia coli..

[26] IS 5887 (Part 3):1999: Methods for detection of bacteria responsible for food poisoning, Part-3 General guidance on method for the detection of Salmonella. 1999.

[27] (IS 5887 (Part 7) Methods for detection of bacteria responsible for food poisoning, Part-7, general guidance on methods for isolation and identification of Shigella. 1999. 